\title{
EFEKTIVITAS PROGRAM ADIWIYATA TERHADAP PERILAKU RAMAH LINGKUNGAN WARGA SEKOLAH DI KOTA DEPOK
}

\section{Effectiveness of Adiwiyata Programme towards Sustainable Living Behaviour at Depok City}

\author{
Tirza Carol Gracia Tompodung ${ }^{\mathrm{a}}$, Siti Badriyah Rushayatib ${ }^{\mathrm{b}}$, M. Nur Aidi ${ }^{\mathrm{c}}$ \\ ${ }^{a}$ Kementerian Lingkungan Hidup dan Kehutanan, Gedung Manggala Wanabakti Jl. Gatot Subroto, Senayan, \\ Jakarta Pusat, 102270 -caroltompodung@gmail.com \\ ${ }^{b}$ Departemen Silvikultur, Fakultas Kehutanan, Institut Pertanian Bogor, Kampus IPB Darmaga, Bogor 16680 \\ ${ }^{c}$ Departemen Statistik, Fakultas Matematika dan IPA, Institut Pertanian Bogor, Kampus IPB Darmaga, Bogor \\ 16680
}

\begin{abstract}
Since 2006, Ministry of Environment has promote environmental education, within the framework of a program for education for sustainable development to raise enviromental knowledge and awareness called Adiwiyata. Adiwiyata program runs on a voluntary and formal school in Indonesia. The Adiwiyata school program aims to encourage schools to adopt behaviours that are respectful towards the environment. As a prize of appreciation, the Ministry of Environment gives Adiwiyata awards to a schools that has succeed to met the criteria of green school environment. In 2014, Depok City government proposed nine schools to become National Adiwiyata School, but only six schools has pass the verification of healthy, clean, and beautiful encvironment and was awarded National Adiwiyata thropy and certificate. The study was conducted in order to test the level of knowledge, attitudes and behaviour of the school community that implemented Adiwiyata program, as well as the effectiveness of the program is to improve the knowledge and awaraness through policy insight, implementation of environmental based curriculum, environmental participatory based activity, and sustainable management of supporting facilitie, to support the responsible for the protection and management of environment. The study concluded that Adiwiyata program evident effective to change the green behaviors of school community.
\end{abstract}

Keywords: Adiwiyata, depok, environmental education, green school.

(Diterima: 19-08-2017; Disetujui: 05-10-2017)

\section{Pendahuluan}

\subsection{Latar Belakang}

Masalah lingkungan hidup yang kian berkembang pesat telah mencapai titik penting dalam abad ke- 21 . Pemanasan global, kenaikan limbah padat, polusi nuklir, penurunan area hijau, serta punahnya keanekaragaman hayati merupakan beberapa masalah lingkungan yang sedang terjadi hingga saat ini (Bonnet, 2007). Timbulnya permasalahan lingkungan tersebut tidak lepas dengan adanya peningkatan jumlah populasi manusia di bumi. Peningkatan pertumbuhan manusia atau penduduk yang sangat tinggi tentu saja berdampak luas terhadap keseimbangan ekosistem dimana tekanan lingkungan hidup juga menjadi besar akibat ketergantungan hidup manusia pada alam. Kurangnya kepedulian penduduk terhadap lingkungan hidup juga menjadi faktor pendukung atas rusaknya lingkungan hidup. Bahkan banyak perilaku dan aktifitas penduduk yang cenderung merusak lingkungan, seperti kebiasaan membuang sampah di sembarang tempat mengakibatkan lingkungan menjadi tercemar.

Status Lingkungan Hidup Indonesia (SLHI) memaparkan tercemarnya Daerah Aliran Sungai di Indonesia, seperti sungai Citarum diakibatkan kegiatan masyarakat perkotaan maupun pedesaan yang menyumbang sebanyak 70-80\% sumber pencemar dan
20-30\% berasal dari aktifitas industri/dunia usaha berbadan hukum (KLH, 2013). Berkaitan dengan hal tersebut, Kementerian Lingkungan Hidup telah melakukan survei perilaku pada tahun 2012 yang menyatakan angka Indeks Perilaku Peduli Lingkungan secara nasional yang hanya mencapai angka 0.57 , dimana angka tersebut dinilai masih jauh dari angka 1 (KLH, 2012).

Undang-Undang nomor 32 tahun 2009 menjelaskan masalah lingkungan hidup merupakan masalah yang kompleks sehingga permasalahan lingkungan hidup bukan hanya menjadi tanggung jawab Pemerintah tetapi segenap elemen masyarakat memiliki peran dan tanggung jawab yang sama. Sekolah, sebagai lembaga pendudukan dalam salah satu elemen masyarakat, berkewajiban untuk membangkitkan kepekaan dan kesadaran akan lingkungan pada generasi muda. Sekolah memiliki kewajiban untuk membuka wawasan dan mendidik siswa untuk berinteraksi dan bersikap dengan penuh tanggung jawab khususnya terhadap lingkungan. Lingkungan sekolah merupakan wadah belajar dan pembentukan karakter dan perilaku anak untuk mengembangkan berbagai aspek menyangkut pengembangan sikap, pengetahuan maupun keterampilan. Untuk itu dalam rangka upaya mendukung pengelolaan lingkungan hidup sekaligus meningkatkan pengetahuan masyarakat mengenai lingkungan serta merubah perilaku manusia yang tidak 
ramah lingkungan, dibutuhkan pengenalan akan lingkungan hidup melalui jalur pendidikan sejak dini. Dengan tumbuhnya pemahaman, khususnya bagi Siswa diharapkan akan muncul rasa peduli terhadap lingkungan yang diwujudkan dalam bentuk sikap dan perilaku yang peka dalam memperhatikan lingkungan hidupnya dan akan meningkatkan sikap dan perilaku yang berorientasi pada pengembangan etika bagi individu dan kelompok sosial. Akan tetapi, menjalankan pola lingkungan yang bersih dan sehat serta mengupayakan pelestarian lingkungan hidup di sekolah tidaklah mudah, pada kenyataannya di lapangan masih banyak warga sekolah yang tidak peduli terhadap lingkungan hidup di sekitar sekolah. Kurangnya peran aktif dan sikap apatis para guru, siswa dan karyawan sekolah terhadap pengelolaan sekolah yang berwawasan lingkungan merupakan penyebab utama terjadinya kerusakan lingkungan hidup di lingkungan sekolah, yang kemudian mengakibatkan tidak terciptanya wawasan terkait pelestarian dan perlindungan lingkungan hidup. Sebagai contoh, tidak jarang warga sekolah terutama siswa masih melanggar peraturan tentang kebersihan lingkungan, seperti membuang sampah sembarangan meskipun telah disediakan tempat sampah dengan jumlah yang memadai di sekolah. Kegiatan vandalism terhadap sarana dan prasarana sekolah, atau adanya aksi banalisme terhadap tumbuhan yang tumbuh di lingkungan sekolah juga merupakan ciri-ciri perilaku yang mencerminkan pengelolaan sekolah yang tidak berwawasan lingkungan. Untuk itu, menerapkan pengajaran berbasis lingkungan merupakan bagian terpenting dalam mewujudkan sekolah yang berwawasan lingkungan.

Pendidikan lingkungan hidup (PLH) merupakan salah satu faktor penting untuk meminimalisasi kerusakan lingkungan hidup dan merupakan sarana penting dalam menghasilkan sumberdaya manusia yang dapat melaksanakan prinsip pembangunan berkelanjutan serta memiliki karakter cinta lingkungan sejak dini (Landriany, 2014). PLH dilakukan sebagai upaya untuk meningkatkan pemahaman dan kepedulian masyarakat dalam mencari solusi dan mencegah timbulnya masalah lingkungan di masa yang akan datang. Hal ini sejalan dengan temuan Benedict yang menyatakan bahwa pembelajaran lingkungan secara aktif merupakan kunci untuk mencapai etika dan perilaku lingkungan (Uzun dan Keles, 2012).

Kementerian Lingkungan Hidup dan Kehutanan melaksanakan program pemberdayaan masyarakat pada komunitas pendidikan yang kemudian dikenal dengan Program Adiwiyata, dalam rangka peningkatan peran serta masyarakat, sesuai amanat pasal $70 \mathrm{UU}$ Nomor 32 Tahun 2009 tentang Perlindungan dan Pengelolaan Lingkungan Hidup (PPLH), sebagai tindak lanjut kesepakatan bersama Kementerian Pendidikan Nasional. Program Adiwiyata dilaksanakan secara menyeluruh pada tiap provinsi di Indonesia sejak tahun 2007 (KLH, 2010) dan merupakan strategi percepatan pelaksanaan PLH pada jalur formal, namun tetap bersifat voluntary. Melalui program Adiwiyata diharapkan setiap warga sekolah ikut berpartisipasi aktif dalam setiap kegiatan sekolah yang bertujuan untuk menciptakan lingkungan belajar yang sehat, serta menghindari dampak lingkungan yang negatif. Program Adiwiyata diarahkan kepada sekolah setingkat SD/MI, SMP/MTS, SMA/MA, dan SMK/MAK. Menurut data yang tercatat di Kementerian Lingkungan Hidup hingga tahun 2014 jumlah peserta program sekolah Adiwiyata kurang 887 sekolah dari target yang diharapkan pada tahun 20122014 yaitu hanya sebanyak 5.593 sekolah, dimana sebanyak 2.693 sekolah telah menerima penghargaan Adiwiyata.

Penghargaan Adiwiyata ditujukan kepada sekolahsekolah yang telah dianggap berhasil dalam mewujudkan sekolah berwawasan lingkungan, sebagai wujud apresiasi Pemerintah atas usaha yang telah dilakukan sekolah dalam upaya pelaksanaan perlindungan dan pengelolaan lingkungan hidup. Sekolah-sekolah yang telah menerima penghargaan Adiwiyata kemudian disebut sebagai sekolah berpredikat Adiwiyata, karena dianggap telah berhasil membentuk generasi yang memiliki karakter peduli terhadap lingkungan. Untuk mewujudkan tujuan tersebut program Adiwiyata tidak hanya difokuskan kepada peserta didik namun setiap warga sekolah wajib terlibat dalam setiap kegiatan pembelajaran dan pelestarian lingkungan hidup di lingkungan sekolah (Landriany, 2014). Peran aktif semua unsur tersebut dapat menciptakan proses perbaikan lingkungan hidup oleh warga sekolah secara berkelanjutan. Akan tetapi hingga saat ini belum ada mekanisme monitoring dan evaluasi dari program Adiwiyata yang mendukung teori tersebut, sehingga belum dapat diuji keefektifannya dalam rangka menanamkan karakter peduli lingkungan hidup kepada warga sekolah, apalagi penghargaan bukan merupakan tujuan dari program Adiwiyata.

Tahun 2014 Kota Depok telah mendapatkan 6 penghargaan Adiwiyata untuk kategori Nasional. Penelitian yang dilakukan oleh Bamberg dan Möser mengenai psikologi lingkungan menyatakan bahwa peningkatan pengetahuan tentang lingkungan hidup dapat meningkatkan kepedulian dan kesadaran, namun tidak selalu menghasilkan perubahan perilaku pada siswa (Bamberg and Möser, 2007). Penelitian serupa juga dilakukan terhadap pendidikan lingkungan hidup pada sekolah menengah atas dan universitas di Hungaria yang menghasilkan dampak dari pendidikan lingkungan belum dapat diukur secara langsung dan belum ada batas yang dapat diidentifikasi antara penelitian yang terfokus pada pola perilaku dan usulan kebijakan mengenai tantangan dan strategi PLH itu sendiri (Zsóka et al., 2012).

\subsection{Tujuan}

(1) Mengidentifikasi pengetahuan, sikap dan perilaku warga sekolah setelah memperolah pendidikan lingkungan hidup melalui Program Adiwiyata

(2) Menganalisis implementasi dan keefektifan program Adiwiyata terhadap peningkatan 
kesadaran lingkungan warga sekolah yang mengikuti program Adiwiyata.

\section{Metode Penelitian}

\subsection{Lokasi dan Waktu Penelitian}

Lokasi penelitian difokuskan pada implementasi kebijakan Pendidikan Lingkungan Hidup pada sekolah penerima penghargaan Adiwiyata Nasional. Pada tahun 2014 telah ditetapkan sebanyak 498 Sekolah sebagai sekolah Adiwiyata Nasional dari 30 Provinsi di Indonesia. Kota Depok pada tahun 2014 mendapatkan enam penghargaan Adiwiyata untuk tingkat Nasional. Sekolah tersebut antara lain SDN Anyelir 1, SDN Pondok Cina 1, SMP N 8 Depok, SMA Lazuardi Global Islamic School, SMAN 2 Depok, dan SMAN 4 Depok.

Penelitian dilakukan dengan mengambil studi kasus pada tiga jenjang sekolah dasar, menengah dan umum di Kota Depok, yaitu pada sekolah penerima penghargaan Adiwiyata Nasional, dan sebagai pembanding juga dilakukan penelitian pada sekolah yang mengikuti program Adiwiyata namun tidak menerima penghargaan Adiwiyata Nasional, serta sekolah yang tidak mengikuti program Adiwiyata (SNA).Waktu peneltian dilakukan pada bulan Mei 2015 - Agustus 2016.

\subsection{Populasi dan Sampel}

Populasi dalam penelitian ini adalah warga sekolah pada sembilan sekolah, yaitu pada 3 sekolah Adiwiyata Nasional, 3 sekolah Adiwiyata, dan 3 sekolah nonAdiwiyata. Jumlah responden yang dijadikan sampel pada masing-masing sekolah ditentukan sebanyak 40 sampel, sehingga total sampel dalam penelitian ini adalah sebanyak 360 sampel (Tabel 1).

Tabel 1. Distribusi Sampel Responden Menurut Strata Sekolah

\begin{tabular}{|c|c|c|c|}
\hline Skor & $\begin{array}{c}\text { Sekolah Adiwiyata Penerima } \\
\text { Penghargaan Adiwiyata Nasional }\end{array}$ & $\begin{array}{c}\text { Sekolah Adiwiyata, tidak menerima } \\
\text { Penghargaan Adiwiyata Nasional }\end{array}$ & Sekolah Non Adiwiyata \\
\hline SD & $\begin{array}{l}\text { - Murid kelas } 1-3: 15 \text { orang } \\
\text { - Murid kelas } 4-6: 15 \text { orang } \\
\text { - Guru: } 5 \text { orang } \\
\text { - Lain-lain: } 5 \text { orang } \\
\text { - Murid } 30 \text { orang }\end{array}$ & $\begin{array}{l}\text { - Murid kelas } 1-3: 15 \text { orang } \\
\text { - Murid kelas } 4-6: 15 \text { orang } \\
\text { - Guru: } 5 \text { orang } \\
\text { - Lain-lain: } 5 \text { orang } \\
\text { - Murid } 30 \text { orang }\end{array}$ & $\begin{array}{l}\text { - Murid kelas } 1-3: 15 \text { orang } \\
\text { - Murid kelas } 4-6: 15 \text { orang } \\
\text { - Guru: } 5 \text { orang } \\
\text { - Lain-lain: } 5 \text { orang } \\
\text { - Murid } 30 \text { orang }\end{array}$ \\
\hline SMP & $\begin{array}{l}\text { - Guru: } 5 \text { orang } \\
\text { - Lain-lain: } 5 \text { orang } \\
\text { - Murid } 30 \text { orang }\end{array}$ & $\begin{array}{l}\text { - Guru: } 5 \text { orang } \\
\text { - Lain-lain: } 5 \text { orang } \\
\text { - Murid } 30 \text { orang }\end{array}$ & $\begin{array}{l}\text { - Guru: } 5 \text { orang } \\
\text { - Lain-lain: } 5 \text { orang } \\
\text { - Murid } 30 \text { orang }\end{array}$ \\
\hline SMA & $\begin{array}{l}\text { - Guru: } 5 \text { orang } \\
\text { - Lain-lain: } 5 \text { orang }\end{array}$ & $\begin{array}{l}\text { - Guru: } 5 \text { orang } \\
\text { - Lain-lain: } 5 \text { orang }\end{array}$ & $\begin{array}{l}\text { - Guru: } 5 \text { orang } \\
\text { - Lain-lain: } 5 \text { orang }\end{array}$ \\
\hline Total & 120 orang & 120 orang & 120 orang \\
\hline
\end{tabular}

\subsection{Teknik Pengumpulan Data}

Data yang digunakan dalam penelitian ini berupa data primer dan sekunder. Data primer meliputi pengetahuan, perilaku dan sikap warga sekolah, serta hasil pengamatan aktifitas warga sekolah di dalam lingkungan sekolah. Data primer akan dikumpulkan dengan menggunakan alat bantu berupa kuesioner.

Metode lain yang digunakan adalah melalui observasi lapang pada lokasi penelitian guna melihat fenomena aktual yang terjadi dan juga mengkaji dokumen-dokumen terkait, kemudian menggolongkan sesuai dengan fenomena tentang implementasi program
Adiwiyata terhadap peningkatan kesadaran lingkungan warga sekolah.

Pengumpulan data kualitatif yang dilakukan dengan menggunakan metode wawancara mendalam melalui informan dengan topik yang terkait (Tabel 2). Sedangkan data sekunder yang dipakai diperoleh dari Kementerian Lingkungan Hidup Republik Indonesia (KLH), Pemerintah Daerah, serta studi kepustakaan melalui pengumpulan data yang bersumber dari hasil kajian dan pelaporan, buku, jurnal, dan literatur.

Tabel 2. Metode Pengumpulan Data

\begin{tabular}{lll}
\hline Teknik Pengumpulan Data & \multicolumn{1}{c}{ Data Yang Dikumpulkan } \\
\hline Kuesioner & a. Pengetahuan terkaiit lingkungan hidup dan sumberdaya alam & Wumber data \\
& b. Sikap & \\
c. Perilaku & - Kebijakan terkait pengelolaan lingkungan hidup & Kepala Sekolah \\
Wawancara & - Keterlibatan warga dalam pengelolaan lingkungan hidup di sekitar sekolah \\
& - Hambatan-hambatan yang dihadapi terkeit implementasi program adiwiyata \\
Observasi Lapang & - Aktivitas warga sekolah & Data di lapangan \\
Analisis Dokumen & - Keadaan lingkungan di sekolah, termasuk kebersihan dan kerapihan & Data Sekunder \\
\hline
\end{tabular}




\subsection{Instrumen Penilaian}

Instrumen pengetahuan, sikap dan perilaku terkait lingkungan hidup responden diukur melalui kuesioner yang diisi oleh sampel selaku self report dengan didampingi oleh peneliti. Kuesioner yang dibagikan berisi masing-masing 6 pertanyaan, dimana setiap pertanyaan memiliki empat pilihan jawaban (Tabel 3). Nilai maksimum dari jawaban masing-masing aspek pertanyaan adalah: 24 , dimana total nilai jawabn dari masing-masing responden adalah 72 .

Tabel 3. Kuantifikasi Variabel

\begin{tabular}{lcll}
\hline $\begin{array}{c}\text { Aspek Pengetahuan } \\
\text { PLH }\end{array}$ & \multicolumn{2}{c}{ Aspek Sikap dan Perilaku PLH } \\
\hline Tidak tahu & 1 & Tidak pernah melakukan & 1 \\
\hline Cukup tahu & 2 & Kadang-kadang melakukan & 2 \\
\hline Tahu & 3 & Sering melakukan & 3 \\
\hline Sangat tahu & 4 & Selalu melakukan & 4 \\
\hline
\end{tabular}

\subsection{Metode Analisis Data}

Teknik analisis yang digunakan pada penelitian ini adalah analisis deskriptif. Analisis deskriptif digunakan untuk mendeskripsikan implementasi program Adiwiyata yang berkaitan dengan penumbuhan sikap cinta dan peduli lingkungan yang akan berlangsung secara terus-menerus. Analisis deskriptif dilakukan dengan membaca tabel untuk melihat kecenderungan dari keefektifan program Adiwiyata dalam meningkatkan wawasan lingkungan para warga siswa dengan membandingkan dengan sekolah pembanding melalui variabel yang digunakan dalam penelitian ini.

Efektivitas adalah ketepatan penggunaan dalam mencapai suatu tujuan. Selanjutnya, efektivitas diartikan sebagai suatu usaha untuk mencapai hasil yang maksimal dengan memanfaatkan segala sumberdaya yang ada (Ilham et al., 2006). Efektivitas menunjukan keberhasilan dari segi tercapai atau tidak tercapainya sasaran tujuan. Jika hasil kegiatan semakin mendekati sasaran tujuan, berarti makin tinggi efektifitasnya. Dapat disimpulkan efektivitas berkaitan dengan terlaksananya tugas pokok, tercapainya tujuan, ketepatan waktu dan partisipasi aktif dari anggota.

Efektivitas suatu program pendidikan diukur melalui evaluasi terhadap tenaga pengajar dan peserta didik, dalam kasus ini warga sekolah Adiwiyata. Untuk itu, suatu evaluasi penting dilakukan untuk mengetahui efektivitas program dalam rangka untuk mengukur sejauh mana peningkatan pengetahuan, ketrampilan, dan perubahan sikap dari warga sekolah, sesuai dengan tujuan pendidikan dan pelatihan itu sendiri (Manullang, 1978). Sehubungan dengan hal tersebut, evaluasi suatu program pendidikan memiliki peran ganda untuk mengetahui efektivitas suatu program pendidikan, serta untuk mendapatkan masukan untuk perbaikan suatu program pendidikan dan pelatihan di masa yang akan datang (Hamblin, 1970). Evaluasi pendidikan merupakan proses untuk menentukan kemajuan apa saja yang telah terjadi terhadap tujuan program yang telah ditentukan dengan menggunakan standar dan biaya yang layak (Moekijat, 1993).

1) Membandingkan pengetahuan warga sekolah terkait lingkungan hidup pada sekolah yang menerapkan program Adiwiyata dengan pengetahuan warga sekolah terkait lingkungan hidup pada sekolah non-Adiwiyata.

2) Membandingkan sikap ramah lingkungan warga sekolah pada sekolah yang menerapkan program Adiwiyata dengan sikap ramah lingkungan warga sekolah pada sekolah non-Adiwiyata.

3) Membandingkan perilaku ramah lingkungan warga sekolah pada sekolah yang menerapkan program Adiwiyata dengan perilaku ramah lingkungan warga sekolah pada sekolah non-Adiwiyata.

4) Menganalisis pengaruh program Adiwiyata dan keefektivan program Adiwiyata terhadap peningkatan kesadaran lingkungan hidup para warga sekolah.

\section{Hasil dan Pembahasan}

\subsection{Kondisi Umum Lokasi Penelitian}

Lokasi penelitian adalah Kota Depok, yaitu pada sekolah negeri peraih penghargaan Adiwiyata Nasional tahun 2014 (Tabel 4), yang kemudian akan dibandingkan dengan sekolah yang mengikuti program Adiwiyata namun tidak mendapatkan penghargaan Adiwiyata Nasional, atau yang hasil verifikasi nasional tidak sebaik sekolah sampel utama (Tabel 5), dan sekolah non Adiwiyata

Tabel 4. Sekolah Adiwiyata Peraih Adiwiyata Nasional

\begin{tabular}{cllc}
\hline No. & \multicolumn{1}{c}{ Nama Sekolah } & $\begin{array}{c}\text { Hasil Verifikasi } \\
\text { Nasional }\end{array}$ \\
\hline 1 & SD Negeri Anyelir 1 & 72.00 \\
2. & SD Negeri Pondok Cina 1 & 74.00 \\
3. & SMP Negeri 8 Depok & & 72.25 \\
4. & SMA Lazuardi Global Islamic & 76.00 \\
5. & School SMA Negeri 2 Depok & & 73.75 \\
6. & SMA Negeri 4 Depok & & 73.25 \\
\hline
\end{tabular}

Tabel 5. Sekolah Adiwiyata bukan penerima Adiwiyata Nasional

\begin{tabular}{clc}
\hline No. & \multicolumn{1}{c}{ Nama Sekolah } & $\begin{array}{c}\text { Hasil Verifikasi } \\
\text { Nasional }\end{array}$ \\
\hline 1 & SD Negeri Sukamaju 5 & 61.50 \\
2. & SDIT AMEC & 69.50 \\
3. & SMP Negeri 7 Depok & 71.00 \\
\hline
\end{tabular}

Berdasarkan tabel 4 maka yang diambil sebagai sekolah sampel utama untuk kategori sekolah penerima penghargaan Adiwiyata Nasional adalah sekolah negeri yang memiliki nilai tertinggi dari hasil verifikasi nasional, yaitu SD Negeri Pondok Cina 1, SMP Negeri 8 Depok, dan SMA Negeri 2 Depok. Untuk kategori sekolah Adiwiyata yang tidak lolos seleksi Adiwiyata 
Nasional, atau tidak menerima penghargaan Adiwiyata Nasional, adalah SD Negeri Sukamaju 5 dan SMP Negeri 7 Depok (Tabel 5). Dikarenakan usulan sekolah Adiwiyata Nasional untuk jenjang sekolah menengah umum dinyatakan lolos seluruhnya, maka diambil sampel sekolah yang memiliki nilai dibawah sekolah sampel utama, yaitu SMA Negeri 4 Depok. Sedangkan untuk sekolah yang berfungsi sebagai sekolah pembanding, diambil sekolah negeri yang tidak mengikuti program Adiwiyata yang lokasinya berada di dekat sekolah sampel utama.

Sebanyak sembilan sekolah negeri yang akan menjadi populasi penelitian, yaitu SD Negeri Pondokcina 1, SMP Negeri 8 Depok, SMA Negeri 2 Depok, SD Negeri Sukamaju 5, SMP Negeri 7 Depok, SMA Negeri 4 Depok, SD Negeri X1, SMP Negeri X2, dan SMA Negeri X3 di Kota Depok.

\subsection{Identifikasi Pengetahuan, Sikap dan Perilaku Warga Sekolah}

Hasil identifikasi terhadap pengetahuan, sikap dan perilaku warga sekolah merupakan hal yang harus dikaji untuk mengetahui peningkatan terkait kesadaran lingkungan warga sekolah setelah menerima Pendidikan Lingkungan Hidup melalui program Adiwiyata, yang dibandingkan dengan hasil data pengetahuan, sikap dan perilaku warga sekolah non Adiwiyata. Identifikasi tersebut dilakukan dengan menggunakan kuesioner yang sama pada masingmasing variabel berisi enam pertanyaan, dengan empat pilihan jawaban (Tabel 6).

Tabel 6. Komponen pendukung upaya sekolah berwawasan lingkungan hidup

\begin{tabular}{lcccc}
\hline \multicolumn{1}{c}{ Sekolah } & Kebijakan & Kurikulum Terintegrasi & Kegiatan & Sarana dan Prasarana \\
\hline SDN Pondok Cina 1 & $\mathrm{v}$ & $\mathrm{v}$ & $\mathrm{v}$ & $\mathrm{v}$ \\
SMPN 8 Depok & $\mathrm{v}$ & $\mathrm{v}$ & $\mathrm{v}$ & $\mathrm{v}$ \\
SMA Negeri 2 Depok & $\mathrm{v}$ & $\mathrm{v}$ & $\mathrm{v}$ & $\mathrm{v}$ \\
SDN Sukamaju 5 & $\mathrm{v}$ & $\mathrm{v}$ & $\mathrm{v}$ & $\mathrm{v}$ \\
SMPN 7 Depok & $\mathrm{v}$ & $\mathrm{v}$ & $\mathrm{v}$ & $\mathrm{v}$ \\
SMAN 4 Depok & $\mathrm{v}$ & - & $\mathrm{v}$ & $\mathrm{v}$ \\
SDN XX & - & - & $\mathrm{v}$ \\
SMPN XX & - & - & $\mathrm{v}$ & $\mathrm{v}$ \\
SMAN XX & - & & \\
\hline
\end{tabular}

Tabel 7. Hasil Identifikasi Pengetahuan, Sikap dan Perilaku Ramah Lingkungan Warga Sekolah

\begin{tabular}{|c|c|c|c|c|c|c|}
\hline \multirow{2}{*}{ Sekolah } & \multicolumn{2}{|c|}{ Pengetahuan } & \multicolumn{2}{|c|}{ Sikap } & \multicolumn{2}{|c|}{ Perilaku } \\
\hline & Rata-rata Skor & Total Skor $(\%)$ & Rata-rata Skor & Total Skor (\%) & Rata-rata Skor & Total Skor (\%)) \\
\hline SDN Pondokcina 1 & 16.9 & 70.4 & 17.5 & 73.2 & 16.4 & 68.3 \\
\hline SMPN 8 Depok & 16.4 & 68.4 & 19.0 & 79.2 & 17.5 & 73.1 \\
\hline SMAN 2 Depok & 20.4 & 84.8 & 21.6 & 90.1 & 21.5 & 90.0 \\
\hline SDN Sukamaju 5 & 15.2 & 63.4 & 17.8 & 74.1 & 15.1 & 62.9 \\
\hline SMPN 7 Depok & 17.8 & 74.2 & 20.5 & 85.5 & 18.1 & 75.5 \\
\hline SMAN 4 Depok & 19.9 & 83.1 & 21.1 & 88.0 & 20.6 & 85.7 \\
\hline SD XX Depok & 10.0 & 41.7 & 10.9 & 45.2 & 12.2 & 50.6 \\
\hline SMPN XX Depok & 15.3 & 63.8 & 16.7 & 69.6 & 12.2 & 50.6 \\
\hline SMAN XX Depok & 14.3 & 59.6 & 13.8 & 57.5 & 11.8 & 48.9 \\
\hline
\end{tabular}

Hasil jawaban warga sekolah terhadap aspek pengetahuan maka dapat terlihat bahwa tingkat pengetahuan terkait lingkungan hidup sekolah yang menerapkan program Adiwiyata lebih tinggi dibandingkan dengan sekolah non-Adiwiyata (Tabel 7). Untuk hasil jawaban pada aspek sikap maka sikap peduli lingkungan sekolah yang menerapkan program Adiwiyata juga lebih tinggi dibandingkan dengan sikap peduli lingkungan warga sekolah pada sekolah nonAdiwiyata. Jawaban terhadap pertanyaan yang terkait dengan aspek perilaku, sebanyak lebih dari 50\% responden pada sekolah yang menerapkan program Adiwiyata maupun sekolah non-Adiwiyata, telah memiliki perilaku ramah lingkungan, kecuali pada sekolah non-Adiwiyata tingkat sekolah menengah umum. Sedangkan tingkat perilakunya, perilaku warga sekolah pada sekolah yang menerapkan program Adiwiyata jelas lebih tinggi dibandingkan dengan perilaku warga sekolah pada sekolah non-Adiwiyata.

Hasil jawaban warga sekolah terhadap aspek pengetahuan maka dapat terlihat bahwa tingkat pengetahuan terkait lingkungan hidup sekolah yang menerapkan program Adiwiyata lebih tinggi dibandingkan dengan sekolah non-Adiwiyata. Untuk hasil jawaban pada aspek sikap maka sikap peduli lingkungan sekolah yang menerapkan program Adiwiyata juga lebih tinggi dibandingkan dengan sikap peduli lingkungan warga sekolah pada sekolah nonAdiwiyata. Jawaban terhadap pertanyaan yang terkait dengan aspek perilaku, sebanyak lebih dari $50 \%$ responden pada sekolah yang menerapkan program Adiwiyata maupun sekolah non-Adiwiyata, telah 
memiliki perilaku ramah lingkungan, kecuali pada sekolah non-Adiwiyata tingkat sekolah menengah umum. Sedangkan tingkat perilakunya, perilaku warga sekolah pada sekolah yang menerapkan program Adiwiyata jelas lebih tinggi dibandingkan dengan perilaku warga sekolah pada sekolah non-Adiwiyata.

Tingkat pengetahuan warga sekolah terkait lingkungan hidup yang pada sekolah yang menerapkan Adiwiyata lebih tinggi dibandingkan dengan pengetahuan terkait lingkungan hidup yang dimiliki oleh warga sekolah non-Adiwiyata dipengaruhi oleh bahan ajar yang disampaikan staf pengajar dan kebijakan yang dibuat oleh kepala sekolah.

Kurikulum tingkat satuan pendidikan (KTSP) pada sekolah yang menerapkan program Adiwiyata telah mengintegrasikan pelajaran Pendidikan Lingkungan Hidup pada semua komponen mata pelajaran wajib, muatan lokal dan pengembangan diri. Artinya semua mata pelajaran telah memiliki rencana pelaksanaan pembelajaran (RPP) yang dikaitkan dengan lingkungan hidup, baik dari metode, model, pendekatan sampai media pembelajaran. Dalam hal teori siswa dibekali dan disisipi materi yang berkaitan dengan lingkungan. Siswa juga diberi tugas yang ada kaitannya dengan lingkungan. Dalam hal praktek siswa diberi kegiatan tentang kecintaan dan peduli pada lingkungan, meskipun sekedar kebersihan kelas. Hal inilah yang membuat tingginya sikap dan perilaku ramah lingkungan pada warga sekolah di sekolah yang menerapkan program Adiwiyata. Adanya pembiasaan yang diterapkan dalam lingkungan sekolah ditujukan untuk perubahan perilaku ke arah yang berwawasan lingkungan.

Sekolah non-Adiwiyata juga memiliki mata pelajaran Pendidikan Lingkungan Hidup. Akan tetapi pelajaran tersebut hanya dijadikan muatan lokal saja dan tidak terintegrasi dengan mata pelajaran lainnya. Berdasarkan hasil wawancara singkat, responden pada sekolan non-Adiwiyata mengatakan bahwa penyampaian materi pendidikan lingkungan hidup tidak kreatif. Hal ini menjadikan materi terkait pendidikan lingkungan sebagai pelajaran yang tidak menarik dan membosankan. Kurangnya sarana dan prasarana yang mendukung pelestarian lingkungan juga menjadi alasan lain rendahnya tingkat pengetahuan, sikap dan perilaku ramah lingkungan warga sekolah. Pada sekolah yang menerapkan program Adiwiyata, sarana dan prasarana pendukung lingkungan hidup dijadikan sebagai media ajar warga sekolah untuk memahami pengelolaan sekolah yang berbudaya lingkungan.

\subsection{Implementasi dan Keefektivan Program Adiwiyata}

Masalah lingkungan hidup terutama berkaitan dengan manusia, bukan hanya lingkungan. Untuk itu pengembangan program pendidikan lingkungan hidup (PLH) harus ditujukan pada aspek tingkah laku manusia, terutama interaksi manusia dengan lingkungan hidupnya serta kemampuannya untuk memecahkan permasalahan lingkungan yang sedang terjadi di sekitarnya. Sehingga setiap teori dalam PLH 175 harus merupakan perpaduan dari dua kelompok tersebut. Namun demikian, PLH di sekolah Adiwiyata bukan hanya berupa teori saja, akan tetapi lebih berupa praktek yang membudaya, sehingga diperlukan sarana prasarana yang mendukung terbentuknya budaya ramah lingkungan tersebut. Untuk mewujudkan hal tersebut program Adiwiyata memiliki empat komponen penting yang harus dicapai oleh sekolah yang menerapkan program Adiwiyata, yaitu : 1) Kebijakan berwawasan lingkungan; 2) Pelaksanaan kurikulum berbasis lingkungan; 3) Kegiatan lingkungan berbasis partisipatif; dan 4) Pengelolaan sarana dan prasarana pendukung sekolah ramah lingkungan.

Program Adiwiyata merupakan suatu program yang bertujuan untuk membentuk karakter manusia yang berwawasan lingkungan dengan cara menciptakan suatu kondisi lingkungan yang memadai, baik ilmu pengetahuan maupun sarana dan prasarana yang terkait upaya pengelolaan lingkungan hidup yang baik. Melalui program Adiwiyata diharapkan cita-cita pembangunan berkelanjutan, khususnya di Indonesia, dapat tercapai.

Adanya kebijakan sekolah yang secara langsung berhubungan dengan upaya mewujudkan lingkungan sekolah yang bersih dan sehat adalah salah satu upaya untuk mewujudkan program Adiwiyata ini dapat terimplementasi dengan baik. Konsep bersih yang dimaksud tidak hanya terkait dengan kondisi fisik, tapi juga berdampak secara psikis. Konsep lingkungan sekolah yang bersih dan sehat menggambarkan sebuah kondisi dimana semua komponen lingkungan sekolah berada dalam kondisi yang seimbang, artinya ada kesesuaian antara daya dukung dan daya tampung serta ketersediaan sarana dan prasarana yang ada di lingkungan sekolah.

Berdasarkan hasil pengamatan lapangan kondisi sekolah yang menerapkan program Adiwiyata terlihat sangat baik, dengan penggunaan lahan yang bijak serta tersedianya sarana dan prasarana pendukung upaya perlindungan dan pelestarian lingkungan hidup yang lengkap. Hal ini disebabkan oleh adanya kebijakan berwawasan lingkungan yang ditetapkan oleh Kepala Sekolah, selaku pimpinan di lingkungan sekolah. Penetapan visi, misi dan tujuan yang berwawasan lingkungan tidak hanya dituangkan ke dalam kurikulum tingkat satuan pendidikan (KTSP) tapi juga disosialisasikan kepada warga sekolah dan juga orangtua siswa. Larangan penggunaan styrofoam, plastik, dan aluminium foil dilingkungan sekolah juga diterapkan, meskipun dari hasil pengamatan lapang masih terdapat kantin yang menjual makanan kemasan. Siswa dianjurkan untuk membawa botol minuman sendiri untuk mengurangi pembelian air minum kemasan, misalnya pada SMA Negeri 4 Depok siswa menyediakan air isi ulang di setiap kelas dengan menggunakan dana kas siswa. Sedangkan untuk wadah airnya disediakan oleh pihak sekolah.

Kebijakan lain yang tidak kalah penting dalam keberhasilan suatu program adalah adanya perencanaan berdasarkan kebutuhan dan pengalokasian anggaran bagi kegiatan pengembangan pendidikan lingkungan hidup. Penetapan kebijakan terkait penggunaan 
anggaran sebanyak $20 \%$ dari total anggaran sekolah untuk kegiatan pengelolaan lingkungan juga dilakukan oleh para sekolah yang menerapkan program Adiwiyata. Kegiatan yang dimaksud dapat berupa kegiatan penanaman pohon, kegiatan aksi kebersihan di lingkungan sekolah, maupun kali atau sungai di daerah kota Depok, hingga kegiatan peningkatan kapasitas terkait pelestarian dan pengelolaan lingkungan hidup untuk staf sekolah, baik pengajar dan staf administrasi sekolah.

Pelibatan siswa secara aktif merupakan pendekatan, strategi metode, dan teknik pembelajaran yang diterapkan oleh para guru pada sekolah Adiwiyata. Selain hal tersebut, para guru juga mengembangkan isu lokal (daerah) dan isu global yang terkait dengan PPLH. Pendidikan lingkungan hidup juga telah diintegrasikan secara maksimal dengan mata pelajaran yang diajarkan pada sekolah yang bersangkutan. Partisipasi Orangtua Siswa juga memegang peranan penting, yaitu sebagai peran pendukung agar pengetahuan terkait kegiatan pelestarian dan perlindungan lingkungan hidup yang didapat Siswa di sekolah dapat diteruskan oleh orangtua di lingkungan rumah. Misalnya kerjasama antara guru dan orangtua siswa sudah diterapkan pada SD Negeri Pondok Cina 1, yaitu melalui pertemuan rutin antara guru dan orangtua siswa bulannya. Sebagai data pendukung tambahan, melalui wawancara singkat terhadap beberapa orangtua siswa yang ditemui pada SD Negeri Pondokcina 1, orangtua siswa tersebut telah mengenal program Adiwiyata dan sangat mendukung program tersebut. Diakui orangtua siswa, di lingkungan rumah siswa menjadi lebih peduli akan kebersihan dan kerapihan, serta rajin mengumpulkan sampah untuk dipakai sebagai bahan baku untuk membuat barang yang dapat didaur ulang, dan bernilai ekonomis.

Tujuan dari upaya sekolah dalam kegiatan berbasis partisipatif adalah mengembangkan kegiatan ekstrakurikuler yang terkait dengan pelestarian dan pengelolaan lingkungan hidup, misalnya kegiatan yang melibatkan kreatifitas dan inovasi Siswa yang memanfaatkan barang bekas dan/atas sampah menjadi barang yang berguna dan memiliki nilai jual. Selain hal tersebut, pemanfaatan lahan dan fasilitas sekolah untuk mendukung upaya pelestarian dan pengelolaan lingkungan hidup.

Umumnya kegiatan lingkungan berbasis partisipatif pada sekolah Adiwiyata adalah melalui program "Jumat Bersih", telah dilaksanakan oleh keenam sekolah yang mengikuti program Adiwiyata tersebut. Sekolah SMA Negeri 2 Depok selalu mengadakan lomba kebersihan kelas setiap bulan dengan tujuan untuk memotivasi siswa agar mengkondisikan keadaan kelas dalam keadaan bersih. Hadiah yang diberikan adalah piala bergilir dan uang tunai kepada pemenang lomba. Dana pembelian hadiah tersebut didapat dari hasil penjualan kompos dan hasil ketrampilan daur ulang yang dibuat oleh para siswa.

\subsection{Efektivitas Program Adiwiyata}

Program Adiwiyata memiliki empat komponen penting dalam penerapannya. Komponen tersebut adalah kebijakan yang mendukung upaya perlindungan dan pengelolaan lingkungan hidup, kurikulum berbasis pengetahuan lingkungan hidup, kegiatan pelestarian lingkungan hidup yang berbasis partisipatif, dan pengelolaan sarana dan prasarana pendukung upaya perlindungan dan pengelolaan lingkungan hidup. Melalui komponen-komponen tersebut, warga sekolah di diarahkan untuk mulai membiasakan diri dalam melestarikan lingkungan.

Tingkatan pengetahuan, sikap, dan perilaku yang dimiliki oleh para warga sekolah yang menerapkan program Adiwiyata terlihat jauh lebih tinggi jika dibandingkan dengan tingkat pengetahuan, sikap dan perilaku warga sekolah non-Adiwiyata (Gambar 1), yang memperlihatkan bahwa program Adiwiyata terbukti efektif dalam meningkatkan pengetahuan, sikap dan perilaku para warga sekolah.

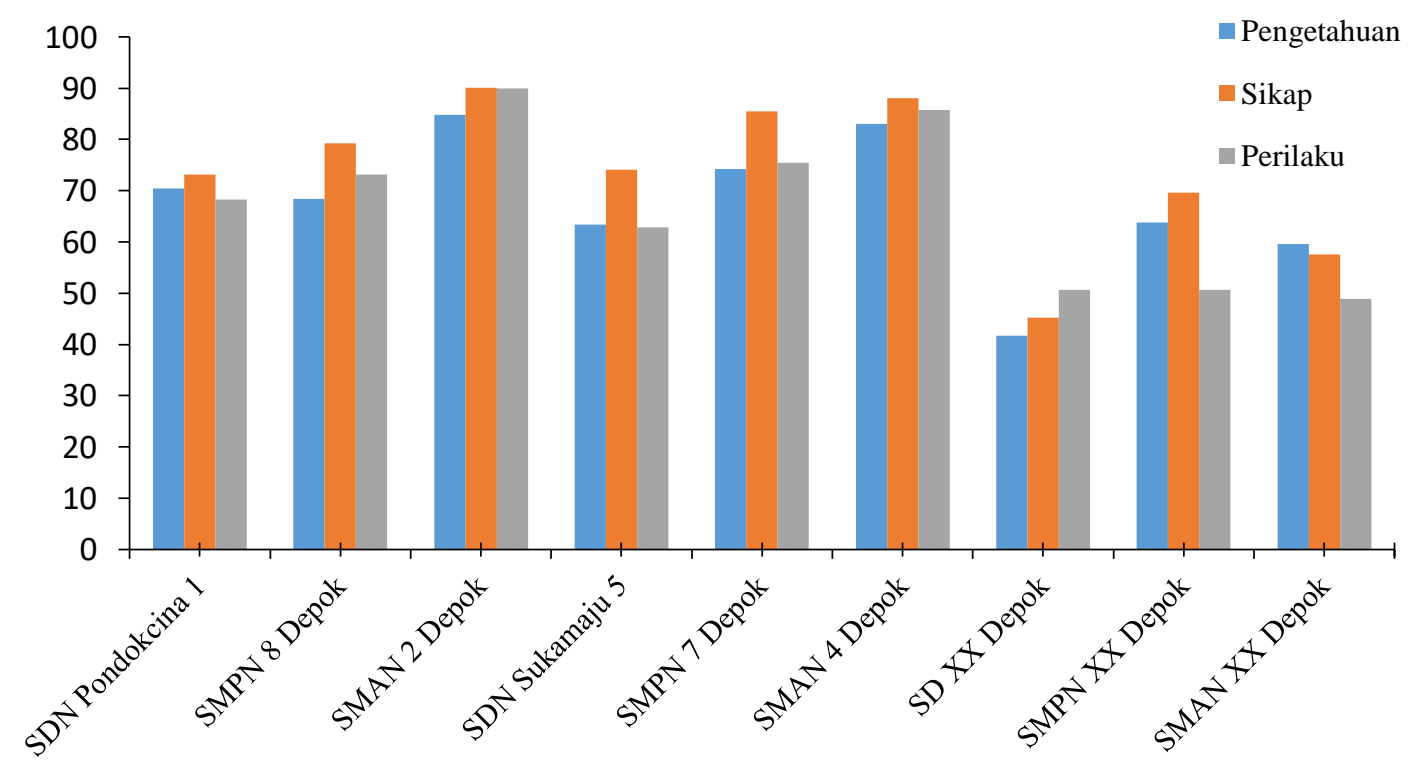


Gambar 1. Tingkat Pengetahuan, Sikap dan Perilaku para warga sekolah dalam Persen (\%)

Kebijakan yang disusun dan diterapkan secara tegas pada sekolah Adiwiyata, menyebabkan terjadinya perubahan sikap dan perilaku warga sekolah. Warga sekolah yang biasanya tidak peduli akan penghematan sumber daya air dan listik, masih membuang sampah sembarangan, dan sebagaimana menjadi tertib pada aturan yang diterapkan. Awalnya karena takut akan diberikan sanksi namun lama kelamaan telah berubah menjadi tanggung jawab untuk melesatarikan alam dan lingkungan.

Metode pembelajaran yang diterapkan pada sekolah Adiwiyata dengan kurikulum yang telah terintegrasi dengan pendidikan lingkungan hidup, juga memberikan dampak yang besar bagi peningkatan pengetahuan para warga sekolah, khususnya siswa. Tidak hanya pada pelajaran ilmu pengetahuan alam, namun pada semua mata pelajaran, siswa dibekali dengan pengetahun-pengetahuan yang terkait dengan lingkungan hidup, termasuk pada pelajaran bahasa, pendidikan agama, dan lain-lain. Siswa juga diberikan keterampilan untuk membuat kerajinan dengan menggunakan sampah plastik menjadi barang yang bernilai ekonomis.

Kegiatan lingkungan berbasis partisipatif dalam program Adiwiyata ditujukan untuk membangun pengetahuan para warga sekolah terkait kegiatankegiatan lingkungan yang dilakukan secara bersamasama dengan pihak lain, atau untuk pihak/lokasi lain. Secara implisit hal ini dimaksudkan untuk memberikan pemahaman kepada para warga sekolah, bahwa masalah lingkungan merupakan masalah yang harus diselesaikan secara bersama-sama dengan seluruh pihak. Seluruh pihak harus memiliki andil dalam mengatasi permasalahan lingkungan yang terjadi. Warga sekolah disadarkan bahwa setiap manusia bertanggung jawab untuk melindungi dan melestarikan lingkungan hidup.

Sarana dan prasarana pendukung ramah lingkungan menjadi media pembelajaran bagi para warga sekolah untuk lebih memahami pengelolaan lingkungan hidup yang baik. namun diatas semuanya itu, pembentukan sikap dan perilaku tetap menjadi faktor utama dalam keberhasilan untuk merubah sikap dan perilaku para warga sekolah terbeban untuk terus melakukan upaya perlindungan dan pengelolaan lingkungan hidup.

Program Adiwiyata dengan keempat komponen telah berhasil mengubah pandangan, sikap dan perilaku para warga sekolah pada sekolah penerima penghargaan Adiwiyata tahun 2014 di Depok.

\section{Kesimpulan}

Tabel 7 dan Gambar 1 menunjukkan perbedaan pengetahuan, sikap dan perilaku para warga sekolah, antara warga sekolah yang menerapkan program Adiwiyata dan sekolah non-Adiwiyata. Melaui hasil tersebut, terlihat bahwa program Adiwiyata terbukti efektif dalam meningkatkan pengetahuan lingkungan hidup para warga sekolah, serta merubah sikap dan perilaku ramah lingkungan warga sekolah. Program Adiwiyata menjadi lebih efektif kareana didukung oleh partisipasi aktif dari warga sekolah, sebab tingkat kualitas kesadaran lingkungan para warga sekolah menjadi lebih tinggi.

\section{Daftar Pustaka}

[1] Bamberg S, Moser G. 2007. Twenty Years After Hines , Hungerford, and Tomera: A New Meta-Analysis of PsychoSocial Determinants of Pro-Environmental Behaviour. Journal of Environmentally Psychology. 27, pp. 14-25.

[2] Bonnett M. 2007. Environmental Education and the Issue of Nature. Journal of Curriculum Studies. 39(6), pp. 707-721.

[3] Ilham, Nyak, H. Siregar, D.S. Priyarsono, 2006. Efektivitas Kebijakan Harga Pangan Terhadap Ketahanan Pangan. Jurnal Agro Ekonomi. 24(2), pp. 157- 177

[4] [KLH] Kementerian Lingkungan Hidup, 2012. Indeks Kualitas Lingkungan Hidup.

[5] [KLH] Kementerian Lingkungan Hidup, 2013. Pedoman Pelaksanaan Program Adiwiyata.

[6] $[\mathrm{KLH}]$ Kementerian Lingkungan Hidup, 2013. Survei Perilaku Masyarakat Peduli Lingkungan.

[7] [KLH] Kementerian Lingkungan Hidup, 2014. Status Lingkungan Hidup Indonesia Tahun 2013.

[8] Landriany E., 2014. Implementasi Kebijakan Adiwiyata Dalam Upaya Mewujudkan Pendidikan Lingkungan Hidup di SMA Kota Malang. Jurnal kebijakan dan pengembangan pendidikan. 2, pp. 82-88.

[9] Undang-undang No. 32 Tahun 2009 Tentang Perlindungan dan Pengelolaan Lingkungan Hidup.

[10] Uzun F.V., O. Keles, 2012. The effects of nature education project in the environmental awareness and behavior. Procedia-Social and Behavioral Sciences. 46, pp. 2912-2916.

[11] Zsóka, Á., Z.M. Szerényi, A. Széchy, T. Kocsis, 2013. Greening Due Environmental Education? Environmental Knowledge, Attitudes, Consumer Behaviour and Everyday Pro-Environmental Activities of Hungarian High School and University Students. Journal of Clearer Production. 48, pp. 126-138. 